\title{
Troska o zdrowie w przekazie pism bł. Marii Angeli Truszkowskiej
}

Ks. dr hab. ROBERT NĘCEK

Uniwersytet Papieski Jana Pawła II w Krakowie

W Katechizmie Kościoła katolickiego można przeczytać, że „życie i zdrowie fizyczne są cennymi dobrami powierzonymi nam przez Boga. Mamy się o nie rozsądnie troszczyć, uwzględniając potrzeby drugiego człowieka i dobra wspólnego"'. Błogosławiona Maria Angela Truszkowska nie znała tej wersji Katechizmu, ale zdawała sobie sprawę $z$ tego, czym zdrowie jest i jaka jest jego wartość w życiu codziennym. Trudno powiedzieć, czy słyszała powiedzenie, iż w zdrowym ciele zdrowy duch, ale jedno jest pewne: była odpowiedzialna za zdrowie swoich sióstr felicjanek.

W liście do o. Honorata Koźmińskiego, pisząc o zdrowiu s. Małgorzaty, stwierdza, że choć jest spokojna, to jednak nie można jej zostawić samej sobie, ale koniecznie należy doradzić się doktora². Błogosławiona Angela wiedziała, że odkładanie decyzji służących zdrowiu może być dramatyczne w skutkach. W tym kontekście zostaną omówione:

${ }^{1}$ Katechizm Kościoła katolickiego, nr 2288.

${ }^{2}$ Por. M.A. Truszkowska, Wybór pism, t. 2, cz. 1. Rzym 1980, s. 81. 
rozumienie zdrowia w chrześcijaństwie, odpowiedzialność bł. Marii Angeli za zdrowie sióstr i troska o siostry chore.

\section{Rozumienie zdrowia w chrześcijaństwie}

Jan Paweł II w orędziu na VII Światowy Dzień Chorego zauważył, że „żadne wołanie wznoszące się z ludzkich serc nie jest równie głośne, jak wołanie o zdrowie i ochronę zdrowia"3. Chrześcijański głos w tej kwestii jest istotny, gdyż codzienność próbuje sprowadzić zdrowie jedynie do sprawności fizycznej, wykluczając pozytywne otwarcie się na cierpienie. Tymczasem chrześcijańskie rozumienie zdrowia wyraża się w trosce godnej człowieka. Wizja ta obejmuje całościowe spojrzenie na osobę ludzką, we wszystkich jej wymiarach. Oznacza to, że brany jest pod uwage nie tylko wymiar fizyczny, ale także duchowy aspekt człowieczeństwa. Wizja zdrowia zgodna $\mathrm{z}$ antropologią chrześcijańską sprawia, że człowiek angażuje się w służbę innym osobom i otwiera się na przyjęcie zbawienia ${ }^{4}$. Dlatego dla właściwego zrozumienia chrześcijańskiej koncepcji zdrowia warto zwrócić uwagę na definicję zdrowia i zdrowie jako dobro wspólne.

\section{Definicja zdrowia}

Zdrowie należy do podstawowych jakości ludzkiego życia. Mimo tego nie brakuje problemów i licznych kon-

${ }^{3}$ Jan Paweł II, Zrzuć swą troskę na Pana, a On cię podtrzyma. Orędzie na VII Światowy Dzień Chorego (8.12.1998), [w:] Jan Paweł II, Dzieła zabrane, t. 4, Kraków 2007, s. 284.

4 Por. R. Nęcek, Troska o zdrowie jako zobowiązanie moralne, [w:] Społeczny wymiar zdrowia, Kraków 2012, s. 16.

82. Ks. dr hab. Robert Nęcek 
trowersji wokół określenia jego istoty. Wydaje się wprost niemożliwe ujednolicenie stanowisk w tej materii, a liczne definicje podejmują jedynie niektóre aspekty omawianej problematyki. Publikacje medyczne podają, że zdrowie samo w sobie jest pojęciem szerokim, można je definiować na różne sposoby i analizować $\mathrm{z}$ różnych punktów widzenia ${ }^{5}$. Posługiwanie się negatywną definicją zdrowia, sprowadzającą je do braku chorób i zaburzeń zdrowotnych, jest niewystarczające. Podobnie w aspekcie pozytywnym, a więc przez powiązanie go z jakością życia człowieka i jego fizycznym potencjałem, pojęcie to staje się niedookreślone. Warto zauważyć, że długotrwały brak zainteresowania istotą zdrowia w pozytywnym znaczeniu spowodował terminologiczny mętlik. Niejednokrotnie teoretycy posługiwali się pojęciem „zdrowie”, a myśleli i mówili jedynie o chorobie ${ }^{6}$.

Istotna rolę $\mathrm{w}$ sposobie pojmowania zdrowia odegrała jedna z najbardziej popularnych definicji sformułowana przez Światową Organizację Zdrowia. Mówi ona, że zdrowie to „całkowity dobrostan fizyczny, psychiczny i społeczny, a nie wyłącznie brak choroby lub niedomagania”. Przytoczona definicja jest godna uwagi z tego powodu, że uwzględnia nie tylko choroby, wykraczając poza ujęcie mechanistyczne, ale nade wszystko zauważa człowieka chorego. Z drugiej jednak strony stwierdzenie „całkowity dobro-

${ }^{5}$ Por. J. Wróbel, Człowiek i medycyna. Teologicznomoralne podstawy ingerencji medycznych, Kraków 1999, s. 138.

${ }^{6}$ Por. Z. Słońska, Zdrowie, [w:] Encyklopedia socjologii, red. W. Kwaśniewicz i in., t. 4, Warszawa 2002, s. 354; R. Nęcek, Troska o zdrowie..., dz. cyt., s. 17.

${ }^{7}$ W.S. Gomułka, W. Rewerski, Encyklopedia zdrowia, Warszawa 1999, s. 359 . 
stan" ma raczej charakter życzeniowy i niemożliwy do spełnienia, nie jest realnym odzwierciedleniem rzeczywistości. Zdrowotny stan doskonałości znajduje się poza zasięgiem ludzkich możliwości, a śmierć pacjenta - nieunikniona przecież - zawsze jest najpoważniejszą porażką ${ }^{8}$.

Dodatkowo definicja ta zaciera granice między poszczególnymi dziedzinami ludzkiego życia i miesza kompetencje służb i nauk zajmujących się osobą ludzką. Nie zwalania od stawiania konkretnych pytań o realne możliwości skutecznego wpływania na zróżnicowane obszary ludzkiej egzystencji środkami, jakimi rozporządza medycyna ${ }^{9}$. Mając tego świadomość, o zdefiniowanie zdrowia pokusiła się Papieska Rada do spraw Duszpasterstwa Służby Zdrowia. W Karcie Pracowników Służby Zdrowia czytamy, że przez pojęcie zdrowia rozumie się „wszystko, co dotyczy zapobiegania, diagnozy, terapii, rehabilitacji zmierzających do lepszej równowagi i dobra fizycznego, psychicznego i duchowego osoby"10. Dodatkowo Karta definiuje pojęcie służby zdrowia jako to wszystko, co „odnosi się do polityki, prawodawstwa, planowania i struktur leczniczych"11. Choć słowo „zdrowie” mieści się w sformułowaniu „służba zdrowia”, to jednak żadna instytucja nie zastąpi ludzkiego współczucia i ludzkiego serca ${ }^{12}$.

${ }^{8}$ Por. R. Nęcek, Troska o zdrowie..., dz. cyt., s. 18.

${ }^{9}$ Por. R. Nęcek. Troska o zdrowie..., dz. cyt., s. 19.

${ }^{10}$ Papieska Rada do spraw Duszpasterstwa Służby Zdrowia, Karta Pracowników Służby Zdrowia, Watykan 1995, nr 9.

${ }_{11}$ Papieska Rada do spraw Duszpasterstwa Służby Zdrowia, Karta Pracowników Służby Zdrowia, dz. cyt., nr 9.

12 Por. R. Nęcek. Troska o zdrowie..., dz. cyt., s. 19. 
Jakże pięknie brzmią w tej perspektywie słowa bł. Marii Angeli Truszkowskiej: „słyszałam, że podobno Magdalena bardzo chora, że jedyny dla niej ratunek - Krynica. Trzeba by ją ratować. Ona tyle pracowała dla Zgromadzenia, to dla niej można zrobić wyjątek, aby ją do wód wysłać. Gdybym ja jechała, to by miała opiekę i koszt niewielki, a więcej jak wody, to by jej pomógł wypoczynek, którego nigdy nie będzie miała, dopóki pozostawać będzie w Warszawie"13.

\section{Zdrowie jako dobro wspólne}

Błogosławiona Maria Angela Truszkowska wiedziała, że zdrowa siostra oznacza prężniejszą działalność zgromadzenia. Dlatego w liście do o. Honorata z 1 maja 1867 roku pisze, że s. Józefa też niedomaga i istnieje „obawa, żeby się nie wywiązała jaka ciężka i niebezpieczna choroba" ${ }^{14}$. Natomiast w liście z 10 stycznia 1869 roku stwierdza, że s. Ewangelista czuje się $z$ dnia na dzień gorzej, s. Janina ma rozwinięte suchoty i pojawia się u niej gwałtowna gorączka. Jeśli tak dalej będzie, to „ani komu nie będzie pracować, ani nawet - ściśle Ustaw zachować nie można" ${ }^{\prime 15}$. Tym sposobem bł. Maria Angela uczestniczyła w trosce o osobowe dobro chorych sióstr, mając na uwadze dobro wspólne. Zdrowie, będące podstawowym dobrem człowieka, wchodzi w zakres dobra wspólnego. Powstaje jednak pytanie: czym jest dobro wspólne?

\footnotetext{
${ }^{13}$ M.A. Truszkowska, Wybór pism, t. 2, cz. 1, Rzym 1980, s. 269.

${ }^{14}$ M.A. Truszkowska, Wybór pism, t. 2, cz. 1, dz. cyt., s. 260.

${ }^{15}$ M.A. Truszkowska, Wybór pism, t. 2, cz. 2, Rzym 1981, s. 117.
} 
Otóż papież Jan XXIII w encyklice Pacem in terris podkreślił, że „prawdziwe dobro wspólne polega przede wszystkim na poszanowaniu praw i obowiązków osoby ludzkiej"16. Chodzi o to, że człowiek może się rozwijać w łączności ze wspólnotą i społeczeństwem. Troska o zdrowie wymaga wejścia w relacje z lekarzami, personelem medycznym i wolontariuszami. Jako przykład można podać różne formy współpracy lekarsko-woluntarystycznej - poradnie zapewniające bezpłatne konsultacje, leki i ubrania dla potrzebujących czy świetną społeczną kuchnię s. Samueli działającą nieprzerwanie od 1872 roku.

Z kategorii dobra wspólnego wynika zatem, aby z jednej strony wytwarzać wartości wspólne, a z drugiej dbać o pełny rozwój osoby człowieka. Dobro wspólne nie staje się więc celem dla samego celu, lecz jego sens przejawia się w służbie osoby ludzkiej. Takie rozumienie dobra wspólnego nie jest naznaczone dowolnością, ale stanowi powinność moralno-prawną wyrażającą się w perspektywie niezbywalnych praw i obowiązków. $Z$ tej racji przedmiotem praw człowieka staje się promocja zdrowia i jego ochrona ${ }^{17}$.

Niewątpliwie człowiek zdrowy narażony jest na utratę zdrowia. Oznacza to, że ludzkie zdrowie ma wymiar relacyjny, a będąc wartością względną, uzależnione jest od wielu czynników. Jednym z takich czynników jest czas, który odciska na życiu swoje piętno. Wraz z upływem lat zmniejsza się sprawność fizyczna, pojawiają się zakłócenia w dziedzinie ludzkiego poznania i funkcjonowania psychiczno-intelektualnego. Dlatego osoba ludzka w zakresie troski o zdro-

\footnotetext{
${ }^{16}$ Jan XXIII, enc. Pacem in terris, Watykan 1963, nr 60.

${ }^{17}$ Por. R. Nęcek, Troska o zdrowie..., dz. cyt., s. 23.
} 
wie ma określone obowiązki, które oznaczają podjęcie odpowiedzialności za swoje zdrowie i zdrowie tych, którzy nie są w stanie o nie zadbać ${ }^{18}$.

\section{Odpowiedzialność bł. Marii Angeli Truszkowskiej za zdrowie sióstr}

Niewątpliwie odpowiedzialność bł. Marii Angeli Truszkowskiej za kondycję zdrowotną sióstr świadczy o jej mądrości. W liście do o. Honorata z 14 września 1868 roku, pisząc o siostrze Kalikście, stwierdza ona: „gdy przyjechała, widziałyśmy ją zmienioną, ale nie widziałyśmy niebezpieczeństwa, a nawet doktor wtenczas zobaczył, gdy było bardzo źle. Do uczynienia ślubów aż musiano ją trzymać, ale myślałyśmy, że to przejdzie. Dopiero doktor wezwany drugi raz powiedział, że jest bardzo źle i że się niedługo skończy. (...) Ja leżałam, nie widziałam jej blisko tydzień, ale byłam o nią niespokojna i dopytywałam się o jej stan"19. To zatroskanie o zdrowie sióstr jest zauważalne na różnych płaszczyznach codzienności. Przejawia się w wezwaniu do troski o zdrowie i w zachęcie do korzystania z odpoczynku.

\section{Wezwanie do troski o zdrowie}

Błogosławiona Maria Angela Truszkowska swoim działaniem promowała postawę bliskości, pozbawioną obojętności i dystansu wobec losu podopiecznych. Założycielka felicjanek

\footnotetext{
${ }^{18}$ R. Nęcek, Troska o zdrowie..., dz. cyt., s. 24.

${ }^{19}$ M.A. Truszkowska, Wybór pism, t. 2, cz. 2, dz. cyt., s. 100-101.
} 
jest dobrym wzorcem do naśladowania, gdyż współcześnie częściej dominuje w świecie „postawa przeciwna: obojętność, brak zainteresowania, które rodzą się z egoizmu, maskowanego przez pozorne poszanowanie sfery prywatnej"20. Jakże więc cierpkie były słowa o niektórych siostrach, które zajmując się chorymi współsiostrami, nie bardzo kwapiły się, by im usłużyć. W liście z 2 sierpnia 1866 roku s. Maria Angela pisze następująco: „jak widać, siostry mało są obznajmione ze sposobem poświecenia dla chorych, najlepszym dowodem jest, że kiedy zapytałam jednej siostry, co jest tej chorej, którą doglądała, odpowiedziała, że nie wie, podobno gorączka. I wiedzieć nie mogła, bo podobno wychodziła czy czytała, kiedy doktor przychodził. Więc jakże może usłużyć chorej, kiedy nie wie, co jej jest, czego potrzebuje"21.

Słowa bł. Marii Angeli odbijają się echem w nauczaniu papieża Franciszka, który podkreślił, że są osoby przestrzegające zasad i zaleceń, lecz stojące w miejscu. Dlatego Chrystus nie może „uczynić z nich zaczynu dla swego ludu, bo nie posuwają się naprzód. Ci, którzy stoją w miejscu, to problem!"22.

\section{Korzystanie z odpoczynku}

Przejawem odpowiedzialności błogosławionej za zdrowie sióstr jest zachęta do korzystania z wypoczynku. Problem

${ }^{20}$ Benedykt XVI, Orędzie na Wielki Post (3.11.2011), „L’Osservatore Romano" 3 (2012), s. 4-5.

${ }^{21}$ M.A. Truszkowska, Wybór pism, t. 2, cz. 1, dz. cyt., s. 157-158.

${ }^{22}$ Franciszek, Bóg szuka nas na marginesie. Słowa z Domu Świętej Marty, Kraków 2017, s. 65-66. 
jest niezwykle ważny, gdyż osoba wypoczęta może spokojnie realizować określone dobro. Lekceważenie wypoczynku prowadzi do przegranej w życiu. Wcześniej czy później przepracowany stanie się łatwym łupem dla świata. Przegra wszystko zmęczony robieniem dobra. Nieprzypadkowo więc w liście z 17 maja 1866 roku, opisując sytuację s. Elżbiety, bł. Maria Angela stwierdza, że siostra ta „zbytecznie pracuje, nie mając chwili wypoczynku, zdrowie jej nawet na tym cierpi i gdyby było komu ją zastąpić, dobrze by było dać jej trochę wypoczynku, bo potrzebuje kuracji. Niech jej przynajmniej Ojciec zaleci, aby się więcej oszczędzała, żeby w końcu nie padła ofiarą swego poświęcenia"23. Chciała przez to powiedzieć, że rozsądniej jest wypocząć i zapobiegać chorobom, niż je później długo leczyć. Warto przypomnieć słowa Benedykta XVI: „musimy być blisko ludzi, prowadzić ich, pomagać im; i to dotyczy zarówno zdrowych, jak i chorych"24.

\section{Troska duchowa o siostry chore}

Błogosławiona Maria Angela Truszkowska w liście z 29 czerwca 1861 roku zauważyła, że s. Junipera jest $\mathrm{w}$ wielkiej biedzie, gdyż poza cierpieniem fizycznym towarzyszą jej też cierpienia moralne. Uległa oschłości, zniechęceniu, niecierpliwości i wszystko ją martwi. Jednocześnie błogosławiona podkreśla troskę, z jaką się otacza siostrę 25 . Troska o siostry chore oznacza pragnienie ich dobra, a dobrem jest to, „co rodzi, chroni i promuje życie, braterstwo

\footnotetext{
${ }^{23}$ M.A. Truszkowska, Wybór pism, t. 2, cz. 1, dz. cyt., s. 153.

${ }^{24}$ Benedykt XVI, Światłość świata, Kraków 2011, s. 129.

${ }^{25}$ Por. M.A. Truszkowska, Wybór pism, t. 2, cz. 1, dz. cyt., s. 81.
} 
i wspólnotę. Odpowiedzialność za bliźniego oznacza zatem czynienie i pragnienie dobra drugiego człowieka, z nadzieją, że i on otworzy się na logikę dobra; interesować się bratem znaczy otworzyć oczy na jego potrzeby"26. W tej perspektywie zostaną omówione: terapeutyczne znaczenie modlitwy i spojrzenie na cierpienie $z$ nadzieją.

\section{Terapeutyczne znaczenie modlitwy}

Niewątpliwie w cierpieniu niektórych sióstr pojawiała się wewnętrzna apatia. Błogosławiona Maria Angela wspomina w liście z 14 września 1868 roku, że najgorliwsza kwestarka s. Kalixta „wczoraj o godzinie 4-tej rano poszła do Pana Jezusa. Doktor utrzymuje, że to był jakiś rodzaj suchot, który gwałtownie się kończy, czasem w 24-ch godzinach. Ona też niedługo się męczyła, bo na dobre, to chyba nie więcej, jak tydzień. Kwestowała z całym zapałem więcej jak rok, kiedy przed dwoma miesiącami, gdy powtórnie wyjeżdżała na kwestę, mówiła do jednej Siostry: czuję się bardzo źle, ale z posłuszeństwa - to choćby umrzeć" ${ }^{\prime 27}$. Jakże piękne jest to świadectwo, które niesie w sobie obraz wyjątkowej religijności siostry i jej postawy rozmodlenia. Błogosławiona Angela - choć sama była wówczas chora - zorganizowała księdza, który przyszedł, wyspowiadał Kalixtę i udzielił jej sakramentu namaszczenia chorych ${ }^{28}$.

Owa modlitewna przestrzeń stała się dla siostry rzeczywistością głębi i mocy, która przeniknęła całą jej egzysten-

\footnotetext{
${ }^{26}$ Benedykt XVI, Orędzie na Wielki Post, dz. cyt., s. 5.

${ }^{27}$ Por. M.A. Truszkowska, Wybór pism, t. 2, cz. 2, dz. cyt., s. 100.

${ }^{28}$ M.A. Truszkowska, Wybór pism, t. 2, cz. 2, dz. cyt., s. 101.
} 
cję: „człowiek epoki cyfrowej podobnie jak człowiek epoki jaskiniowej poszukuje $\mathrm{w}$ doświadczeniu religijnym dróg przezwyciężenia swej ograniczoności oraz zapewnienia bezpieczeństwa swej niepewnej przygodzie na ziemi. Zresztą życie bez horyzontu transcendentnego nie miałoby poczucia wypełnienia i szczęścia, do którego wszyscy dążymy, jest ono bowiem z natury ukierunkowane ku przyszłości, która jeszcze ma się spełnić” ${ }^{29}$. Poprzez modlitwę i sakramenty wychodzi się poza krąg własnych spraw, odzyskuje zdolność zbliżania się do innych, „zwłaszcza w chwilach próby” ${ }^{30}$. Owa terapia modlitewna przyczynia się nie tylko do udźwignięcia cierpienia, ale niejednokrotnie staje się źródłem naprawy zaniedbanych relacji z najbliższymi i przyjaciółmi. Terapia ta zakłada także dyskrecję, która „nie wyklucza modlitwy wspólnej”31. Nie było więc zaskoczeniem, kiedy bł. Maria Angela pisała o siostrze Kalixcie: „kiedym się pytała, czy spokojna, odpowiedziała: jestem spokojna, chyba w godzinę śmierci będę się niepokoić. Dla wszystkich uprzejma, dla tych, co jej służyli"32.

${ }^{29}$ Benedykt XVI, Katecheza o modlitwie (11.05.2011), „KAI”, 12.05. 2005.

30 Benedykt XVI, Modlitwa umacnia naszq więź z Bogiem Ojcem i otwiera serca na potrzeby ludzi (14.12.2011), „L’Osservatore Romano” 2 (2012), s. 50.

31 Benedykt XVI, Jezus z Nazaretu. Od chrztu w Jordanie do Przemienienia, t. 1, Kraków 2007, s. 115.

32 M.A. Truszkowska, Wybór pism, t. 2, cz. 2, Rzym 1980, s. 101. 


\section{Spojrzenie na cierpienie z nadzieją}

Cierpienie jest rzeczywistością głębiej osadzoną w człowieczeństwie niż sama choroba. Z jednej strony budzi współczucie i szacunek, z drugiej zaś onieśmiela. Pojawia się więc potrzeba serca, która pomaga przezwyciężyć onieśmielenie i głęboki imperatyw wiary pozwalający dotknąć nietykalnej tajemnicy. Cierpienie, wyniszczając człowieka, czyni go jednocześnie niejako ciężarem dla otoczenia. Wówczas czuje się on skazany na opiekę i ludzką pomoc ${ }^{33}$. Miała tego świadomość bł. Maria Angela, kiedy w liście z 23 października 1867 roku pisała: „proszę ciągle Pana Jezusa, że kiedy daje cierpienie, żeby dał i łaskę do znoszenia, żeby sam nauczył cierpieć i gdyby mi dał do wyboru, czy cierpieć z weselem, czy miewać objawienia, to bym to pierwsze wybrała, dlatego że ja ani sobie, ani żadnej duszy nie wierzę, że kocha Pana Jezusa, dopóki ochotnie nie znosi cierpienia"34.

Słowa matki Truszkowskiej są wyjątkowe, gdyż ukazują, że źródłem nadziei dla niej jest łączność z Chrystusem. W takim właśnie kontekście papież Benedykt XVI w encyklice Spe salvi zauważył, że „jednostka nie może zaakceptować cierpienia drugiego, jeśli ona sama nie potrafi odnaleźć w cierpieniu sensu, drogi oczyszczenia i dojrzewania, drogi nadziei. Zaakceptować drugiego, który cierpi, oznacza bowiem przyjąć na siebie w jakiś sposób jego cierpienie, tak że staje się ono również moim. Właśnie dlatego jednak, że staje się ono teraz cierpieniem podzielanym, że jest w nim obecny ktoś inny, oznacza to, że światło miłości przenika moje cier-

\footnotetext{
${ }^{33}$ Por. Jan Paweł II, list apost. Salvifici doloris, nr 4.

${ }^{34}$ M.A. Truszkowska, Wybór pism, t. 2, cz. 2, Rzym 1980, s. 7.
} 
pienie”35. Jednocześnie należy podkreślić, że cierpienia nie da się wyeliminować, można je tylko ograniczycic ${ }^{36}$. Cierpienie można zrozumieć jedynie dzięki wierze, która daje możliwość przyjęcia go i przetworzenia od wewnątrz ${ }^{37}$. Wspomina o tych trudnościach błogosławiona, pisząc: „ta choroba nie tylko fizycznie mnie męczy, ale do zupełnego upadku ducha doprowadza. Cierpię moralnie tysiąc razy więcej niż fizycznie, bo cierpię dlatego, że nic cierpieć nie umiem dla Pana Jezusa i coraz większy czuję wstręt do cierpienia i to mię najwięcej przeraża" ${ }^{\prime 3}$. W tej perspektywie z pomocą przychodzi chrześcijaństwo. Otóż Chrystus „na ludzkie pytanie o sens cierpienia nie odpowiada wprost i nie odpowiada w oderwaniu. Człowiek słyszy Jego zbawczą odpowiedź w miarę, jak sam staje się uczestnikiem cierpień Chrystusa" ${ }^{39}$.

Oznacza to, że wiara wyzwalająca nadzieję i pobudzająca do miłości opiera się na prawdzie o człowieku ${ }^{40}$. „Szansa wiary - jak pisał kardynał Ratzinger - jest szansą prawdy; obie się zaciemnia i depcze, lecz nie znikną one nigdy"11.

\section{Zakończenie}

Reasumując, należy stwierdzić, że wezwanie bł. Marii Angeli Truszkowskiej do troski o zdrowie jest jednym $\mathrm{z}$ wy-

${ }^{35}$ Benedykt XVI, enc. Spe salvi, Watykan 2007, nr 38.

${ }^{36}$ Por. Benedykt XVI, enc. Spe salvi, nr 37.

${ }^{37}$ Por. R. Nęcek, Troska o zdrowie jako zobowiq̨zanie moralne, [w:] Społeczny wymiar zdrowia, Kraków 2012, s. 28.

${ }^{38}$ M.A. Truszkowska, Wybór pism, t. 2, cz. 2, Rzym 1980, s. 6-7.

39 Jan Paweł II, list apost. Salvifici doloris, nr 26.

${ }^{40}$ Por. R. Nęcek, Troska o zdrowie..., dz. cyt., s. 11.

${ }^{41}$ J. Ratzinger, Służyć prawdzie, Wrocław 1986, s. 66. 
miarów ludzkiej i boskiej mądrości. Zdrowie będące wartością codzienną wymaga mądrej pielęgnacji. Z drugiej jednak strony jest wartością utracalną, co pociąga za sobą ból i cierpienie. Kiedy zawiodą medyczne środki leczenia, wyzwala się pełnia mocy mająca swoje źródło w modlitwie. Dlatego błogosławiona napisała: „choć takie życie bardzo ciężkie, a śmierć przy takim cierpieniu jeszcze cięższa. Przypisuję tylko modlitwie Ojca, że teraz choć cierpię bardzo, to cierpię trochę spokojniej jak dawniej"42.

${ }^{42}$ M.A. Truszkowska, Wybór pism, t. 2, cz. 2, Rzym 1980, s. 280-281. 